\title{
The Coexistence of Autoimmune Pancreatitis and Crohn's Disease in an Adolescent Case
}

\author{
Adolesan Bir Olguda Otoimmun Pankreatit ve \\ Crohn Hastalığı Birlikteliği
}

\section{Guzide DOGAN®, Ozlem AKGUN®, Sevim OZDEMIR $\odot$, Esen Gul UZUNER $\odot$, Sule POTUROGLU $\odot$}

Ethics Committee Approval: Not Applicable.

Conflict of Interest: The authors declare that they have no conflict of interest.

Funding: None.

Informed Concent: Informed consent was taken.
Cite as: Dogan G, Akgun O, Ozdemir S, et al. The Coexistence of Autoimmune Pancreatitis and Crohn's Disease in an Adolescent Case. Medeniyet Med J. 2020;35:62-6.

\begin{abstract}
Although autoimmune pancreatitis is not seen in children frequently, it is included in the etiology of chronic pancreatitis. A 16-year-old girl who was diagnosed with chronic pancreatitis 4 months previously, presented to the outpatient clinic with abdominal pain on the epigastric region, and left lower abdominal quadrant and bloody defecation. Remarkable laboratory test results were as follows: amylase: $109 \mathrm{U} / \mathrm{L}$, lipase: $196 \mathrm{U} / \mathrm{L}$, Ig G:13.70 g/L, IgG4:2.117 g/L, fecal calprotectin $573 \mu \mathrm{g} / \mathrm{g}$. In the MRCP examination, revealed enlarged pancreas with a heterogeneous appearance, dilated main pancreatic duct. Colonoscopic and histopathological findings were consistent with inflammatory bowel disease. The case was diagnosed as Crohn's disease coursing with autoimmune pancreatitis. Clinical and laboratory findings regressed after steroid treatment. Autoimmune pancreatitis is important in that it is rarely seen in children and though less frequently it is associated with Crohn's disease. It should be kept in mind that inflammatory bowel disease may develop in the follow-up of autoimmune pancreatitis and autoimmune pancreatitis may be present in the etiology of chronic pancreatitis.
\end{abstract}

Keywords: Autoimmune pancreatitis, Crohn's disease, children, inflammatory bowel disease

öz

Otoimmün pankreatit çocuklarda sık görülmese de, kronik pankreatit etiyolojileri içinde yer almaktadır. Dört ay önce kronik pankreatit tanısı alan 16 yaşındaki kız olgu, epigastrik bölge ve sol alt kadranda olan karın ağrısı ve kanlı dışkılama nedeniyle polikliniğe başvurdu. Laboratuvar tetkiklerinde amilaz: 109 U/L, lipaz: 196 U/L, Ig G:13.70 g/L, IgG4:2.117 g/L, fekal kalprotektin $573 \mu \mathrm{g} / \mathrm{g}$ saptandı. MRCP incelemesinde pankreas heterojen görünümde ve boyutu artmış, ana pankreatik kanal genişlemiş idi. Kolonoskopik inceleme ve histopatojik bulgular inflamatuvar bağırsak hastalı̆̆ı ile uyumlu idi. Olguya otoimmun pankreatitle birlikte seyreden Crohn hastalığı tanısı konuldu. Steroid tedavisi sonrası klinik ve laboratuvar bulguları geriledi. Otoimmun pankreatit çocuklarda nadir görülmesi ve az sıklıkta da olsa Crohn hastalığı ile birliktelik göstermesi nedeniyle önemlidir. Otoimmun pankreatit takibinde inflamatuvar bağırsak hastalığı gelişebileceği ve kronik pankreatit etiyolojilerinde otoimmun pankreatit de olabileceği unutulmamalıdır.

Anahtar kelimeler: Otoimmun pankreatit, Crohn hastalığı, çocuklar, inflamatuvar bağırsak hastalığı

(c) Copyright Istanbul Medeniyet University Faculty of Medicine. This journal is published by Logos Medical Publishing. Licenced by Creative Commons Attribution-NonCommercial 4.0 International (CC BY-NC 4.0)
Received: 27 October 2019

Accepted: 24 January 2020

Online First: 28 February 2020

Corresponding Author: G. Dogan

ORCID: 0000-0003-4291-7282 Health Science University Haseki Training and Research Hospital, Depertment of Pediatric Gastroenterology, Istanbul, Turkey

guzidedogan@gmail.com

\section{O. Akgun}

ORCID: 0000-0001-7216-0562

Health Science University Haseki

Training and Research Hospital Depertment of Pediatrics, Istanbul,

Turkey

S. Ozdemir

ORCID: 0000-0003-4270-6370

Health Science University Haseki

Training and Research Hospital Depertment of Radiology, Istanbul,

Turkey

E.G. Uzuner

ORCID: 0000-0002-2732-1651

Health Science University Haseki

Training and Research Hospital Depertment of Pathology, Istanbul,

Turkey

S. Poturoglu

ORCID: 0000-0002-2722-9636

Health Science University Haseki

Training and Research Hospital

Depertment of Gastroenterology, Istanbul, Turkey

This study was presented during $7^{\text {th }}$ Child Friendship Congress, 7-9 March 2019, Istanbul, Turkey 


\section{INTRODUCTION}

Autoimmune pancreatitis (AIP) is a rare chronic autoimmune disease of the pancreas and it is often seen in adults ${ }^{1-3}$. The literature related to AIP in children is usually reported as case reports and data on its incidence in children are not yet available in the literature ${ }^{2}$. In this article, we report a case of AIP- related chronic pancreatitis, that later received the diagnosis of Crohn's disease $(\mathrm{CH})$.

\section{CASE PRESENTATION}

A 16-year-old girl presented with nausea, abdominal pain, bloody diarrhea. She had a history of intermittent low back pain and epigastric pain that was present for about two years. It was learned that the abdominal pain increased in severity with intake of fatty foods and did not awaken her from sleep at night. Four months ago she had abdominal pain and nausea. High amylase and lipase levels were detected (amylase: $66 \mathrm{U} / \mathrm{L}$, lipase: 117 $\mathrm{U} / \mathrm{L}$ ). Magnetic resonance cholangiopancreatography (MRCP) was performed. The pancreas was heterogeneous in appearance and its size was increased and the main pancreatic duct was enlarged. Chronic pancreatitis was diagnosed with these findings. She was referred to our center with complaints of intermittent bloody diarrhea, nausea and abdominal pain in the epigastric region and in the left lower abdominal quadrant for the last three months. Abdominal pain did not regress with defecation. She had bloody diarrhea 2-3 times a day. There was no history of weight loss, malaise, night sweats or drug use. Her family history was unremarkable. The case was hospitalized with preliminary diagnoses of chronic pancreatitis and inflammatory bowel disease (IBD).

Physical examination revealed tenderness in the epigastric region and in the left and right lower quadrant. PE of the anorectal region and other systems was unremarkable. Some laboratory test results were as follows: leukocyte count: 6,700/ $\mathrm{mm}^{3}$, hemoglobin: $12.4 \mathrm{gr} / \mathrm{dL}$, platelets : 234,000 /mm³ ${ }^{3}$ CRP: $14.2 \mathrm{mg} / \mathrm{L}$, amylase: $109 \mathrm{U} / \mathrm{L}$, lipase: 196 U/L (N:7-39), aspartate aminotransferase (AST): $27 \mathrm{U} / \mathrm{L}$, alanine aminotransferase (ALT):34 U/L, ESH:20 mm/h, B12: $250 \mathrm{pg} / \mathrm{mL}$, folic acid: $3.44 \mathrm{ng} / \mathrm{ml}$, ferritin: $17 \mathrm{ng} / \mathrm{mL}$, vitamin $\mathrm{D}: 38$ $\mathrm{ng} / \mathrm{mL}$, serum immunglobulin (Ig) G:13.70 g/L, Ig A: $2.09 \mathrm{~g} / \mathrm{L}$, Ig M: $0.92 \mathrm{~g} / \mathrm{L}, \operatorname{IgG} 4: 2.117 \mathrm{~g} / \mathrm{L}$ $(\mathrm{N}: 0.110-1.570)$. Other biochemical parameters, cystic fibrosis gene, cationic trypsinogen, trypsin inhibitor gene mutations were normal, viral panel (CMV, rubella, EBV, toxoplasma, hepatitis $A, B)$, ANA, ANCA, ASCA autoantibodies and PPD test were negative. There was large amounts of leukocytes and erythrocytes in the stool sample. Fecal cultures, amoeba antigen and clostridium difficile toxin tests were negative. Fecal calprotectin was high, with $573 \mu \mathrm{g} / \mathrm{g}(\mathrm{N}:<50 \mu \mathrm{g} / \mathrm{g})$.

Abdominal ultrasonographic examination revealed heterogeneity in pancreatic parenchyma, pancreatitis sequelae, cystic formations in pancreas head $(9 \mathrm{~mm})$, corpus $(22 \times 21 \mathrm{~mm})$ and tail $(28 \times 24 \mathrm{~mm})$, dilatation of Wirsung duct at corpus level. Gallbladder and intrahepatic biliary tract were normal. On the magnetic resonance imaging (MRI) and MRCP of the abdomen; the enlarged pancreas was heterogeneous in appearance (Figure 1a). Significant enlargement was detected in the main pancreatic duct. There were cystic formations (sizes $26 \times 18 \mathrm{~mm}, 27 \times 25 \mathrm{~mm}$ ) without prominent contrast enhancement in the corpus and tail, and solid septal component (Figure 1b). There was no increase in wall thickness without intraabdominal lymphadenomegaly.

Colonoscopy showed milimetric aphthous ulcers on the ileocecal valve and all along the colon, except the transverse colon. Colonic mucosa was erythematous, friable and edematous except transverse colon. In the rectum, fibrin large-sized coated ulcerated areas were detected. Upper gastrointestinal endoscopy showed the presence of distal esophagitis and antral gastritis. In histopathologic examination transverse colon mucosa was normal (Figure 2a), and in all other areas of 


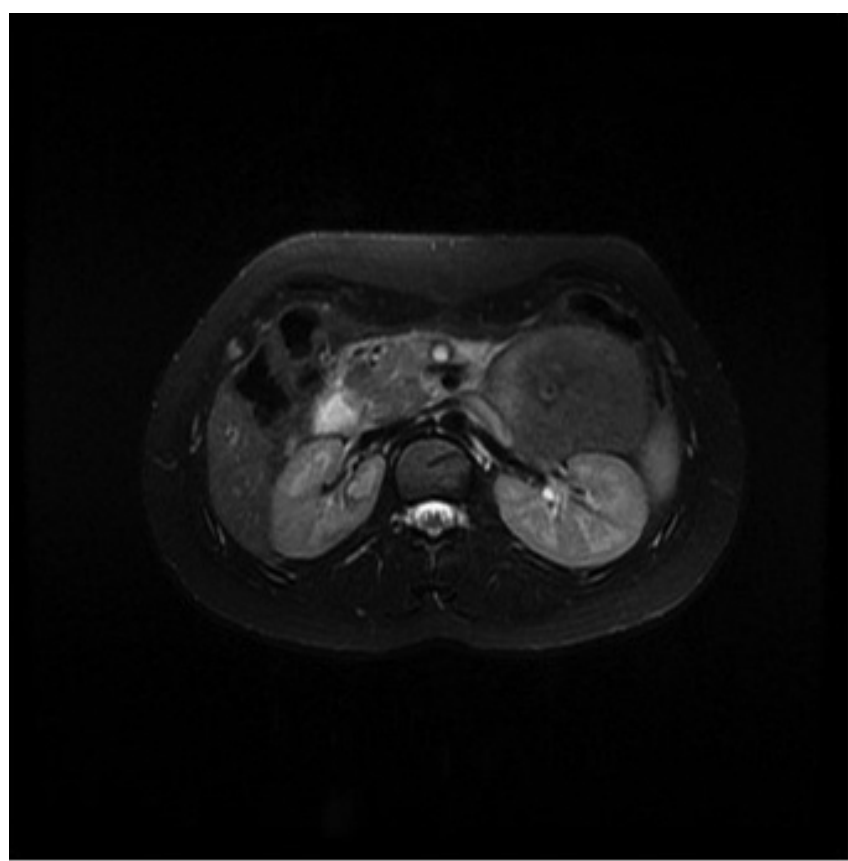

Figure 1a

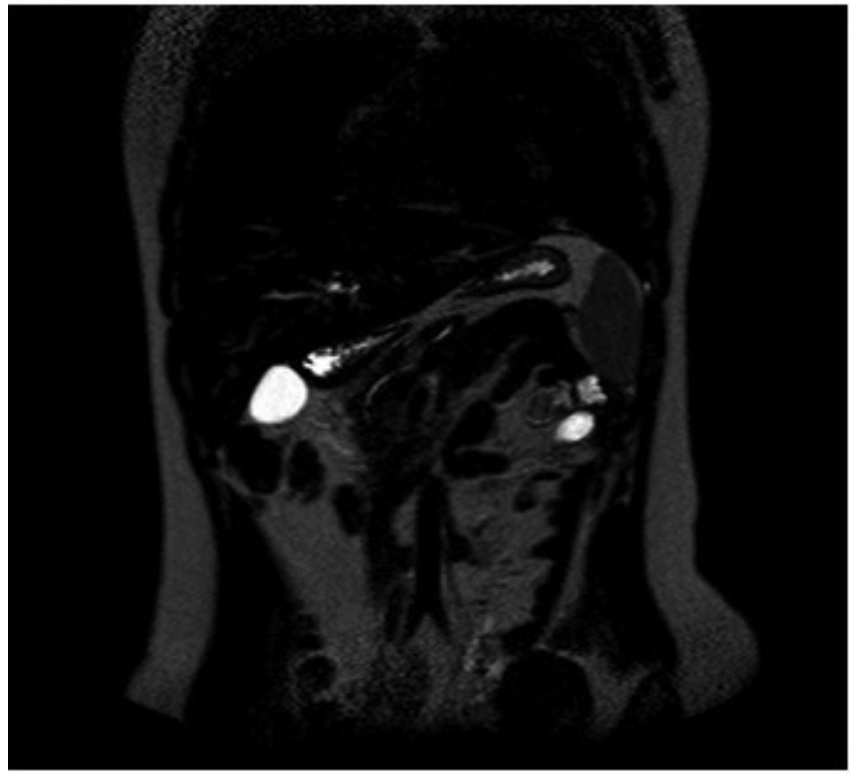

Figure 1c

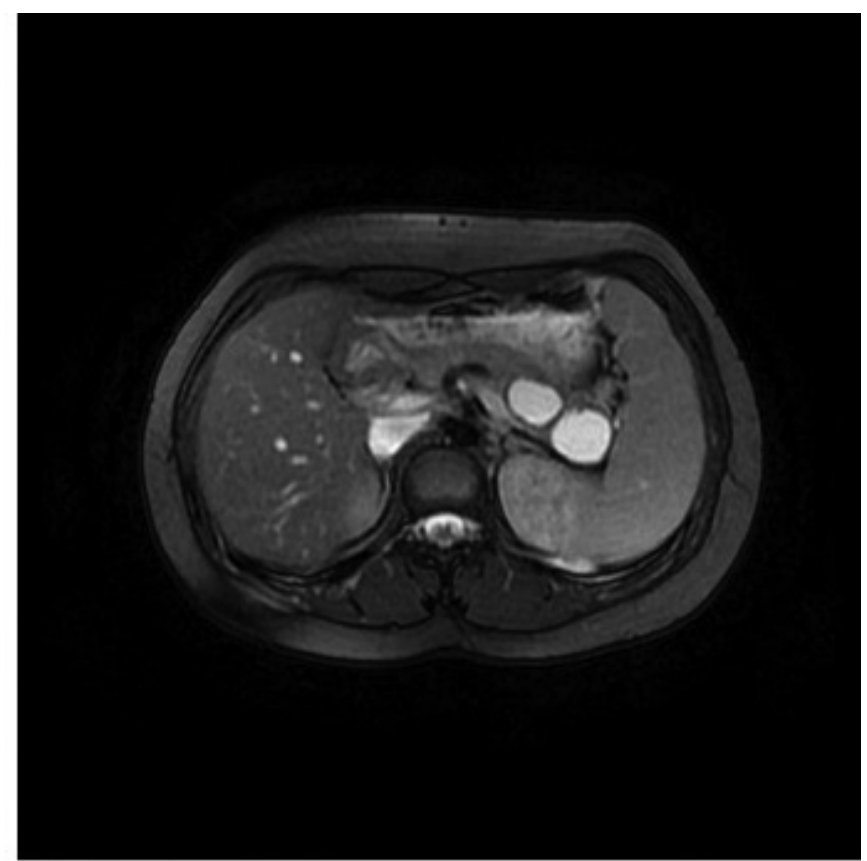

Figure 1b

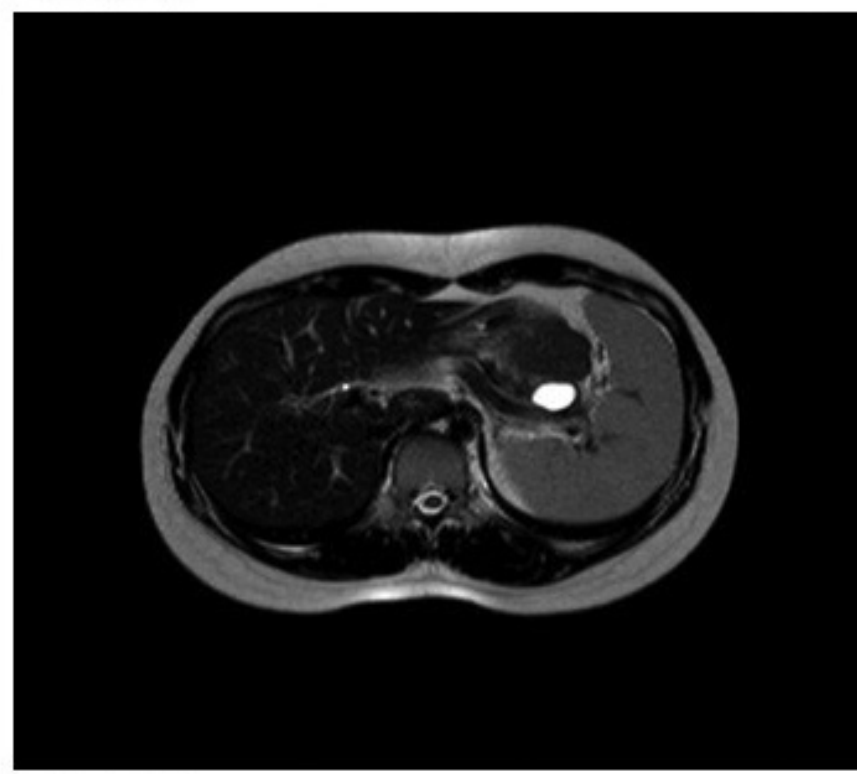

Figure 1d

Figure 1a. Increased size and increase of signal in the axial fat-printed T2A sequence consistent with edema-inflammation at the head of the pancreas. b: Thin-walled cysts with homogeneous, non-septal solid component localized at the tail of the pancreas, shown in axial fat-printed T2A (the largest ones $26 \times 18 \mathrm{~mm}$ and $27 \times 25 \mathrm{~mm}$ ). c: In the coronal plane, the non fat printed T2A sequence is normal, the size of the pancreas head and body is normal, the size increase in the first examination and the T2 signal increase consistent with edema-inflammation are not observed in this examination. Pancreatic duct width is within normal limits. d: Homogeneous cyst, with no septal and solid component, which decreased in size compared to previous examinations $(20 \times 13 \mathrm{~mm})$, was observed in the tail of the pancreas in axial non fat printed T2A sequences. The other cysts in the first examination had completely regressed.

the biopsy specimen cryptitis, crypt distortion, intense mixed inflammatory cells were seen in lamina propria (Figure $2 \mathrm{~b}$ ). The histopathologic examination of the gastroscopic biopsy specimen revealed the presence of chronic esophagitis and H. pylori-negative antral gastritis. 


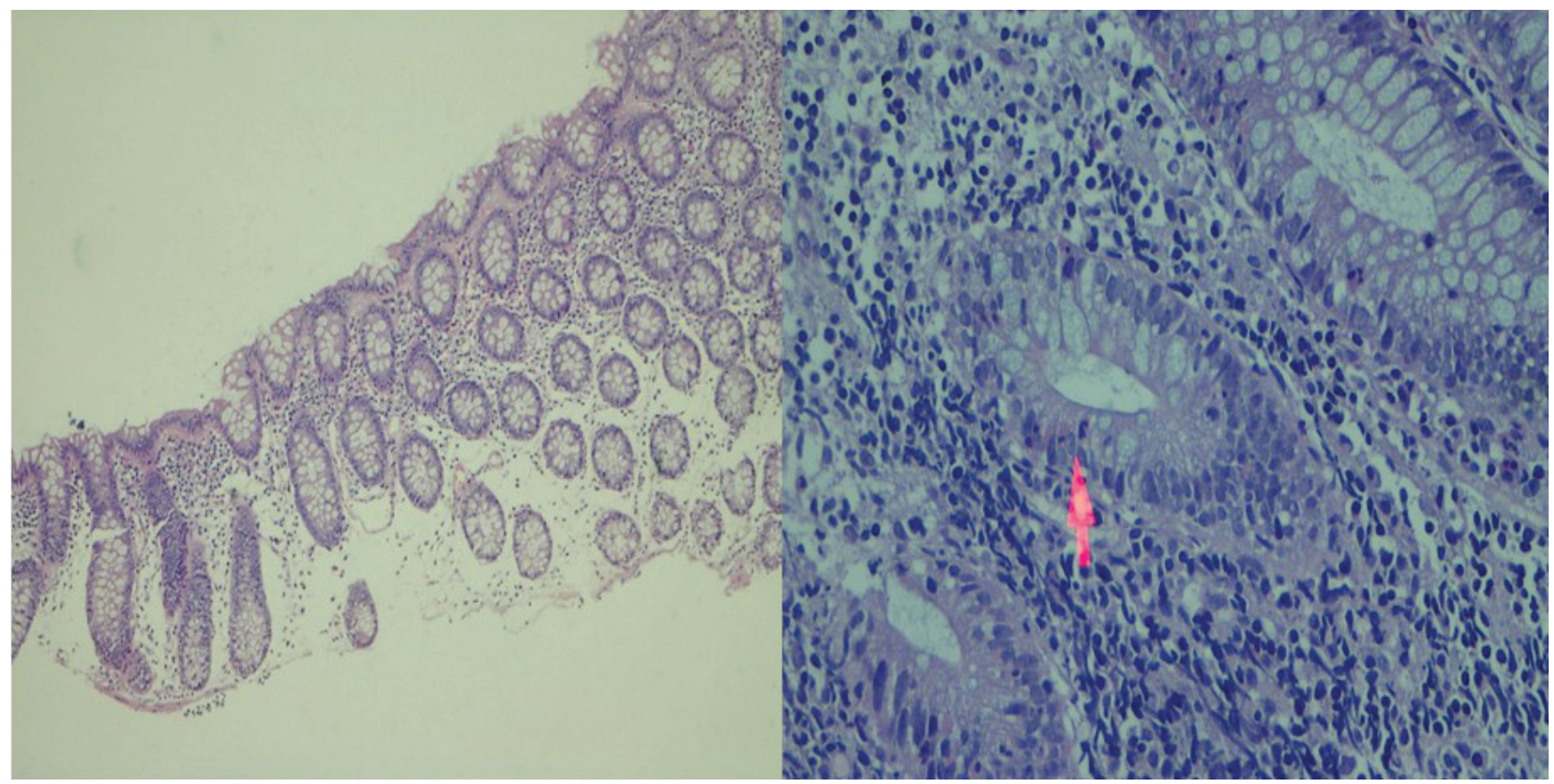

Figure 2a: Normal transverse colonic mucosa H\&EX100. b: Cryptitis, intense mixed inflammatory cells in the lamina propria H\&EX400.

Pancreatic biopsy was quested for the determination of the type of autoimmune pancreatitis; but the parents did not allow the biopsy procedure. The case was diagnosed with AIP accompanied by Crohn's disease because the MRI and MRCP imaging of the abdomen revealed diffuse growth in the head of the pancreas, enlargement of the main pancreatic duct, and pseudocyst formation; amylase, lipase and Ig G4 were high; and there was a coexistence with the histopathological diagnosis of IBD. Intravenous steroid and proton pump inhibitör treatment were initiated. Mesalamine tablets and mesalamine enema treatments were also given for Crohn's disease. On the $14^{\text {th }}$ day of the streoid treatment, amylase, lipase and CRP values returned to normal. Three months later, the control MRCP showed that the pancreatic head and corpus dimensions returned to normal, pseudocysts had shrunk (one 20x13 mm) and disappeared (Figure 1c and 1d).

\section{DISCUSSION}

Autoimmune pancreatitis is the chronic inflammation of the pancreas. The frequency of all types of chronic pancreatitis ranges between $2 \%$ and $6 \%$ in adults. It can be seen with symptoms such as mild pain in the epigastric region, obstructive jaundice and loss of appetite. It can also be seen with autoimmune diseases like primary biliary cirrhosis, primary sclerosing cholangitis, IBD, systemic lupus erythematosus, Sjögren's syndrome and retroperitoneal fibrosis ${ }^{4}$.

In 2011, the International Association of Pancreatology published International Consensus Diagnostic Criteria (ICDC) in the diagnosis of autoimmune pancreatitis. Five criteria consisting of imaging, serology, other organ involvement, histology and response to steroid treatment and subgroups as type 1 and type 2 were determined ${ }^{5,6}$. Type 2 is more common in the pediatric and young adult age groups. It is not related to Ig G4, and it is more commonly seen in associattion with $\mathrm{IBD}^{7}$. Ulcerative colitis (UC) is seen more commonly with AIP. The severity of bowel disease increases the risk of AIP development ${ }^{8}$. The incidence rate of AIP before development of IBD is $20 \%$, while the rate of simultaneous onset of both diseases is $26 \%$, and the rate of AIP after remission of IBD is 
$54 \%$. Our case is in the least common group. Our patient was first diagnosed with AIP, and three months later with Crohn's disease. In our case, although type 2 compatible AIP was seen, an increase in the value of serum IgG4, which is used to differentiate from type 1 , was also found. Murata et al. ${ }^{9}$ reported three cases with autoimmune pancreatitis; a 10-year-old patient was only diagnosed with AIP, 4 and 16 year old patients with UC. The IgG4 level of the 16-year-old patient was as high as in our case. In childhood, the distinction between two types cannot always be made clearly. We could not evaluate lymphoplasmocytic or granulocytic infiltration and Ig G4-positive cells because we did not perform pancreatic biopsy in our case.

In 2017, an international consensus was reported in the treatment of autoimmune pancreatitis. Steroids are used as first-line therapy in the induction of remission ${ }^{10}$. In our case we also started steroid treatment in the induction of remission in IBD therapy. Improvement in the symptoms of our case and a decrease in amylase and lipase values were observed in a short time.

\section{CONCLUSION}

Autoimmune pancreatitis is rare in children and it is rarely associated with Crohn's disease. It should be kept in mind that inflammatory bowel disease may develop during the follow-up of autoimmune pancreatitis and autoimmune pancreatitis may be an etiologic factor of chronic pancreatitis.

\section{REFERENCES}

1. Lee HM, Deheragoda $M$, Harrison P, et al. Autoimmune pancreatitis in children: A single centre experience in diagnosis, management and long term follow up. Pancreatology. 2019;19:169-76. [CrossRef]

2. Kołodziejczyk E, Wejnarska K, Oracz G. Autoimmune pancreatitis in the paediatric population-review of the literatüre and own experience. Dev Period Med. 2016;20:279-86.

3. Tunçel D, Özgüven BY, Sarı AG, et al. Nonneoplastic Lesions of the Pancreas: A Retrospective Analysis of 20 Cases. Med Bull Sisli Etfal Hosp 2018;52:31-5. [CrossRef]

4. Kasapoğlu B, Türkay C. Otoimmun pankreatit. Güncel Gastroenteroloji. 2008;12:34-8.

5. Shimosegawa T, Chari ST, Frulloni L, et al. International consensus diagnostic criteria for autoimmune pancreatitis: guidelines of the International Association of Pancreatology. Pancreas. 2011;40(3):352-8. [CrossRef]

6. Zen Y, Grammatikopoulos T, Hadzic N. Autoimmune pancreatitis in children: insights into the diagnostic challenge. J Pediatr Gastroenterol Nutr. 2014;59:e42-5. [CrossRef]

7. Suk Lee Y, Kim NH, Hyuk Son J, et al. Type 2 Autoimmune Pancreatitis with Crohn's Disease. Intern Med. 2018;57:2957-62. [CrossRef]

8. Lorenzo D, Maire F, Stefanescu C, et al. Features of Autoimmune Pancreatitis Associated With Inflammatory Bowel Diseases. Clin Gastroenterol Hepatol. 2018;16:59-67. [CrossRef]

9. Murata S, Yoden A, Aomatsu T, Inoue K, Tamai H. Three cases of childhood-onset autoimmune pancreatitis. Nihon Shokakibyo Gakkai Zasshi. 2014;111:1632-9.

10. Okazaki K, Chari ST, Frulloni L, et al. International consensus for the treatment of autoimmune pancreatitis. Pancreatology. 2017;17:1-6. [CrossRef] 